\title{
THE LARVA OF ROTHIUM SONORENSIS MOORE \& LEGNER WITH A KEY TO THE KNOWN LARVAE OF THE GENERA OF THE MARINE BOLITOCHARINI (COLEOPTERA : STAPHYLINIDAE) ${ }^{1}$
}

\author{
BY IAN MOORE \\ Department of Entomology, University of California, \\ Riverside, California 92521
}

Larvae of Staphylinidae are difficult to associate with adults except in some specialized habitats where few species are present. In the intertidal habitat it has been possible to associate adults and larvae when they are present. The present larva is identified by its size, color and association with adults.

Rothium sonorensis Moore \& Legner (1977) is a recently described genus and species of intertidal rove beetle from the Gulf of California belonging to the tribe Bolitocharini.

\section{LARVA OF ROTHIUM SONORENSIS MOORE \& LEGNER}

Length $5.1 \mathrm{~mm}$. Body elongate, slightly convex, parallel, sclerites pale brown with the center of tergite eight dark brown, appendages and intersegmental membranes cream with the ungues brown. Surface smooth and shining. Head subquadrate, a little longer than wide, with a small dark eye spot midway between the antennal fossa and the lateral margin; epicranial suture $\mathrm{Y}$ shaped. Clypeus narrowed and truncate in front, without teeth. Antennal fossa located at inner end of arm of epicranial suture. Antenna three-segmented; first segment a little longer than wide; second segment about one and one-half times as long as first and a little wider, widest near apex; apex bearing an "acorn seta" which is more than three times as wide and about as long as third segment; third segment about four times as long as wide, tapered to pointed apex which bears a short seta. Mandible arcuate, acute at tip, with a large central tooth internally. Maxillary palpus three-segmented with the first two segments subequal in length, the second a little narrower than first, third segment narrower and a little longer than second, narrowed gradually to pointed apex. Lacinia triangular, minutely

${ }^{1}$ Manuscript received by the editor December 28, 1977. 


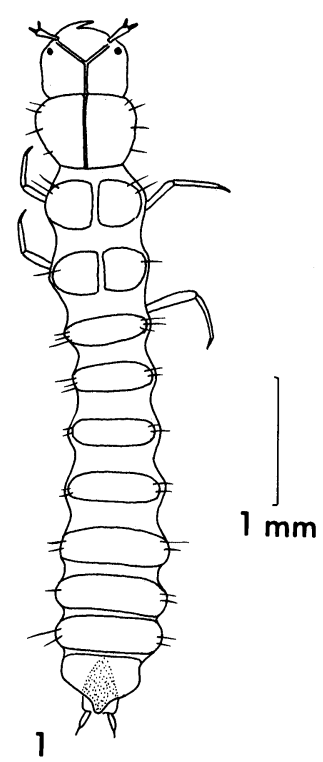

Figure 1. Larva of Rothium sonorensis Moore \& Legner; dorsal aspect.

hooked and with a small tooth at apex and three other small teeth internally just below apex; with a row of long setae beginning at basal half and diminishing in length to base. Labial palpus twosegmented, first segment slightly more than twice as long as wide, parallel sided; second segment narrower but almost as long as first, tapered to apex. Ligula longer and wider than first segment of labial palpus, narrowed to truncate apex. Pronotum a little wider than long; quadrate; with the apex arcuate, apical angles broadly rounded, sides straight and somewhat converging to narrowly rounded basal angles; base almost straight; surface with scattered long setae. Mesonotum and metanotum of about equal size and shape; about as wide as pronotum and only half as long; each side with a row of five setae below the anterior margin, two discal setae, a row of three setae along the base and three setae in the lateral series. Tergites one through seven similar, with the first about as wide but not as long as metanotum, each succeeding very slightly wider and somewhat longer than the preceding so that tergite seven is wider than the metanotum and about as long; each with a discal 

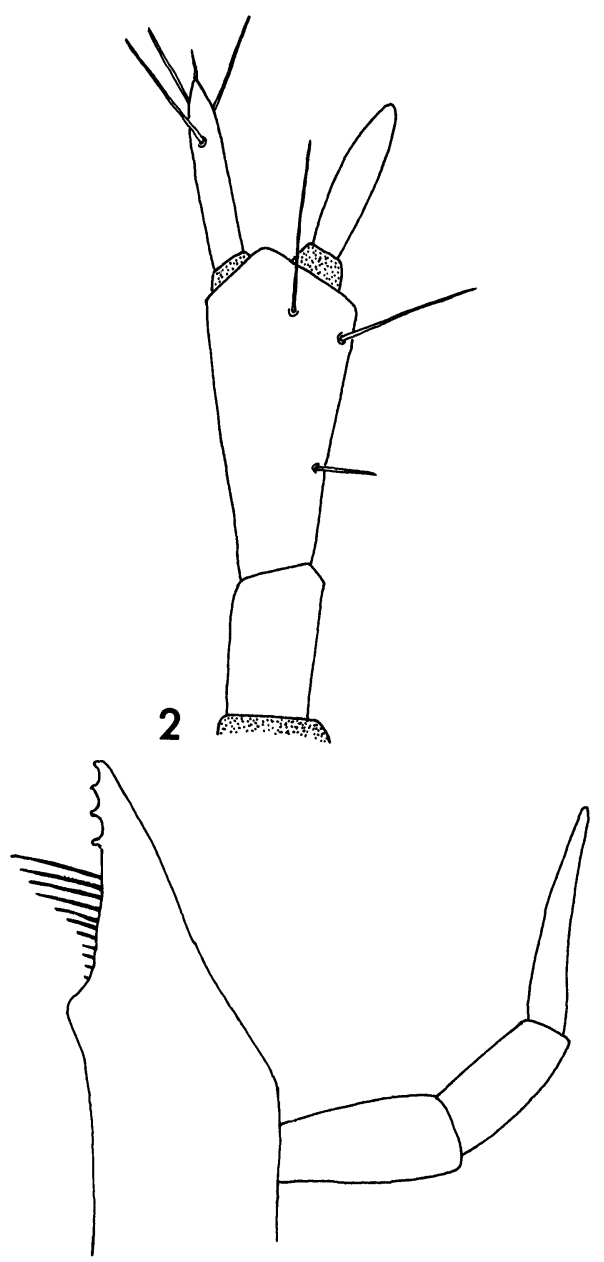

4
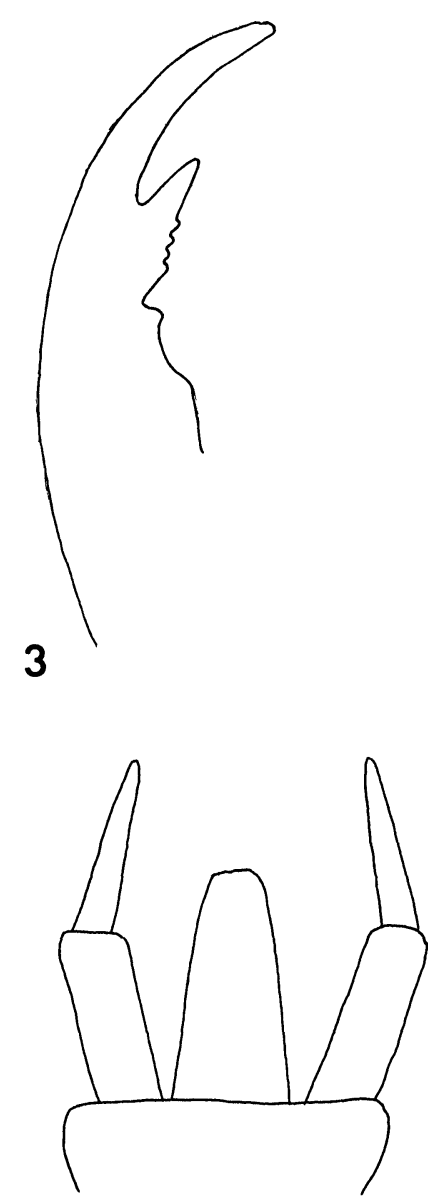

5

Figures 2-5. Larva of Rothium sonorensis Moore \& Legner. Fig. 2, left antenna, dorsal aspect. Fig. 3, left mandible, ventral aspect. Fig. 4, right maxilla, ventral aspect. Fig. 5, labium. 
row of ten setae, two setae laterally at the anterior margin and several other scattered lateral setae. Ninth tergite narrower than eighth, which is produced posteriorly in its central third in a narrowly rounded dark lobe that probably represents opercula for an osmeterium. Urogomphus one-segmented with a long seta at pointed apex. Pseudopod represented by a short narrow projection at the apex of a small broad triangular organ, the entire structure not more than half as long as the urogomphus, the cylindrical apical projection about one-third as wide as the urogomphus.

One specimen taken in company with five adults at Mexico, Sonora, Tide Pool Beach, 29.49-112.40, 20 March 1974, V. Roth and W. Brown, collectors. Another specimen was taken by V. Roth at Mexico, Sonora, Punta Cirio, 29.50-112.39, 12-20 January 1974 , from intertidal rock crevice.

Among the marine Bolitocharini the larva of Phytosus nigriventris Chevrolat was described by Fauvel (1862), that of Halmaeusa atriceps (Waterhouse) by Paulian (1949) (as Antarctophytosus), those of Liparocephalus cordicollis LeConte and Diaulota densissima Casey by Saunders (128) and Chamberlin and Ferris (1929). These descriptions were reviewed by Moore (1956) who described the larvae of three more species of Diaulota and gave a key to the genera and the species of Diaulota.

\section{KEY TO THE KNOWN LARVAE OF THE GenERA OF THE MARINE BOLITOCHARINI}

1. Apex of ninth abdominal segment truncate .. Phytosus Curtis Apex of ninth abdominal segment produced in two appendages

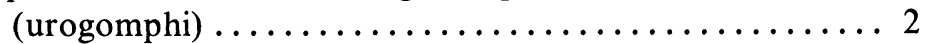

2. Urogomphus not segmented $\ldots \ldots \ldots \ldots \ldots \ldots \ldots \ldots$ Urogomphus segmented ................. 4

3. Antenna 3-segmented ............ Liparocephalus Mäklin Antenna 2-segmented .............. Diaulota Casey

4. Urogomphus one-segmented ..... Rothium Moore \& Legner Urogomphus 2-segmented ........ Halmaeusa Kiesenwetter

\section{Literature Cited}

Chamberlin, J. S. and G. F. Ferris

1929. On Liparocephalus and allied genera. Pan-Pac. Ent. 5: 137-143, 153162. 


\section{Fauvel, Albert}

1862. Notice sur quelques aléochariens nouveaux ou peu connus et description de larves de Phytosus et Leptusa. Ann. Soc. Ent. France, Ser. 4, 2: $81-94$.

\section{MOORE, IAN}

1956. Notes on some intertidal Coleoptera with descriptions of the early stages (Carabidae, Staphylinidae, Malachiidae). Trans. San Diego Soc. Nat. Hist. 12: 207-230.

Moore, IAN AND E. F. Legner

1977. A report on some intertidal Staphylinidae from Sonora, Mexico with four new genera (Coleoptera). Pac. Insects 17: 459-471, 20 Figs.

Paulian, Renaud

1941. Les premier états des Staphylinoidea. Études des morphology comparée. Mém. Mus. Nat. Hist. 15: 1-361, 1367 Figs.

SAUNDERS, L. G.

1929. Some marine insects from the Pacific coast of Canada. Ann. Ent. Soc. Amer. 21: 521-545. 

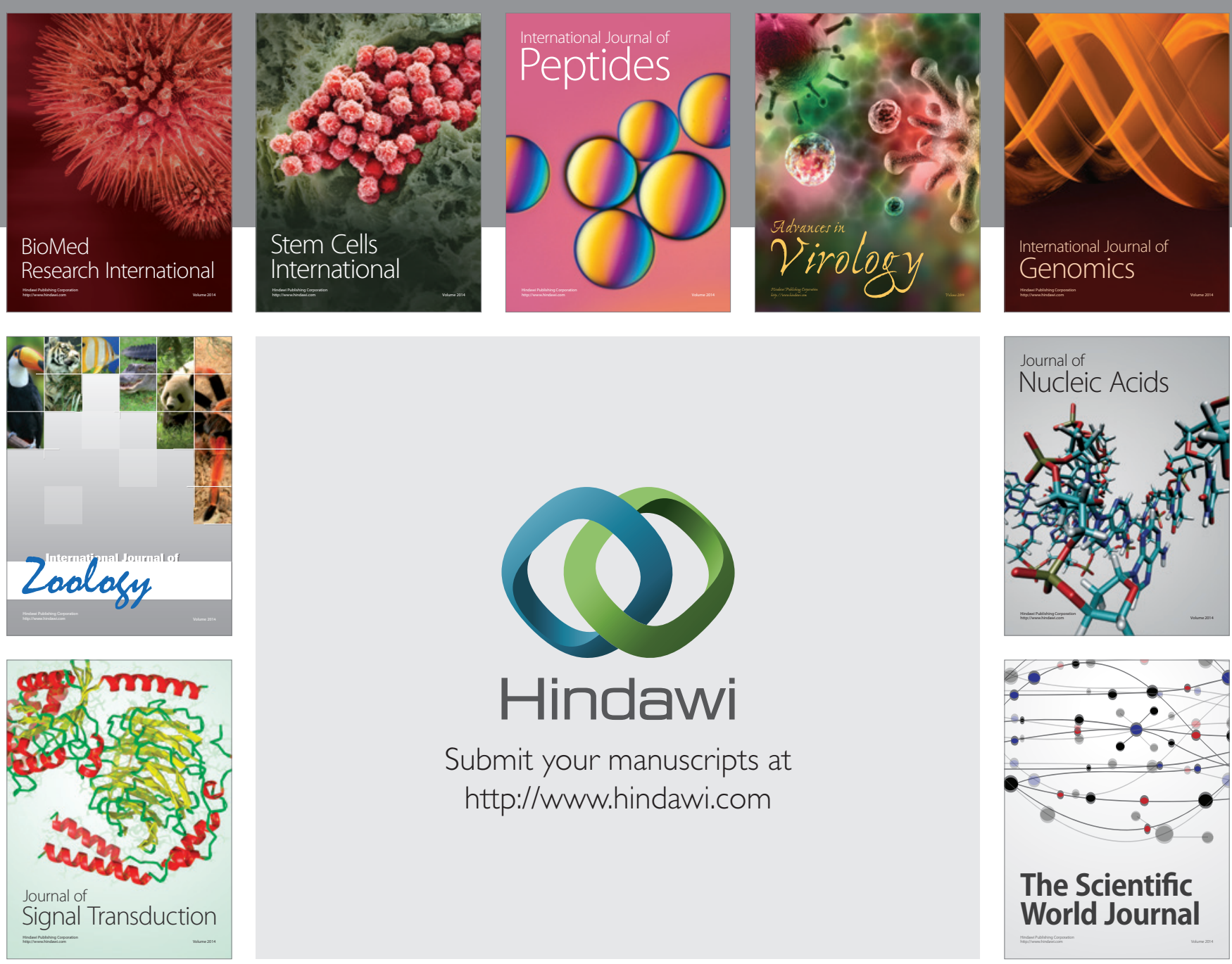

Submit your manuscripts at

http://www.hindawi.com
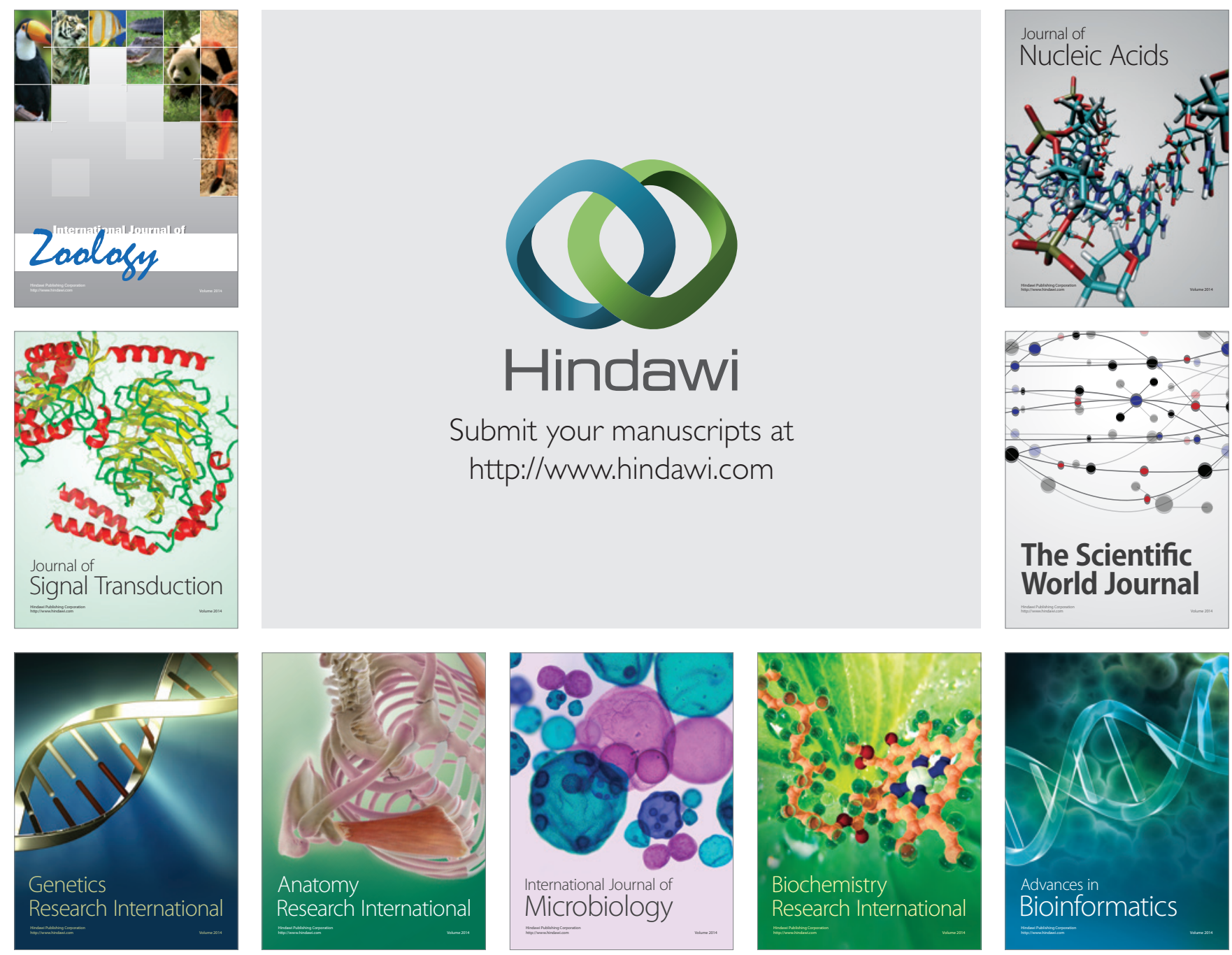

The Scientific World Journal
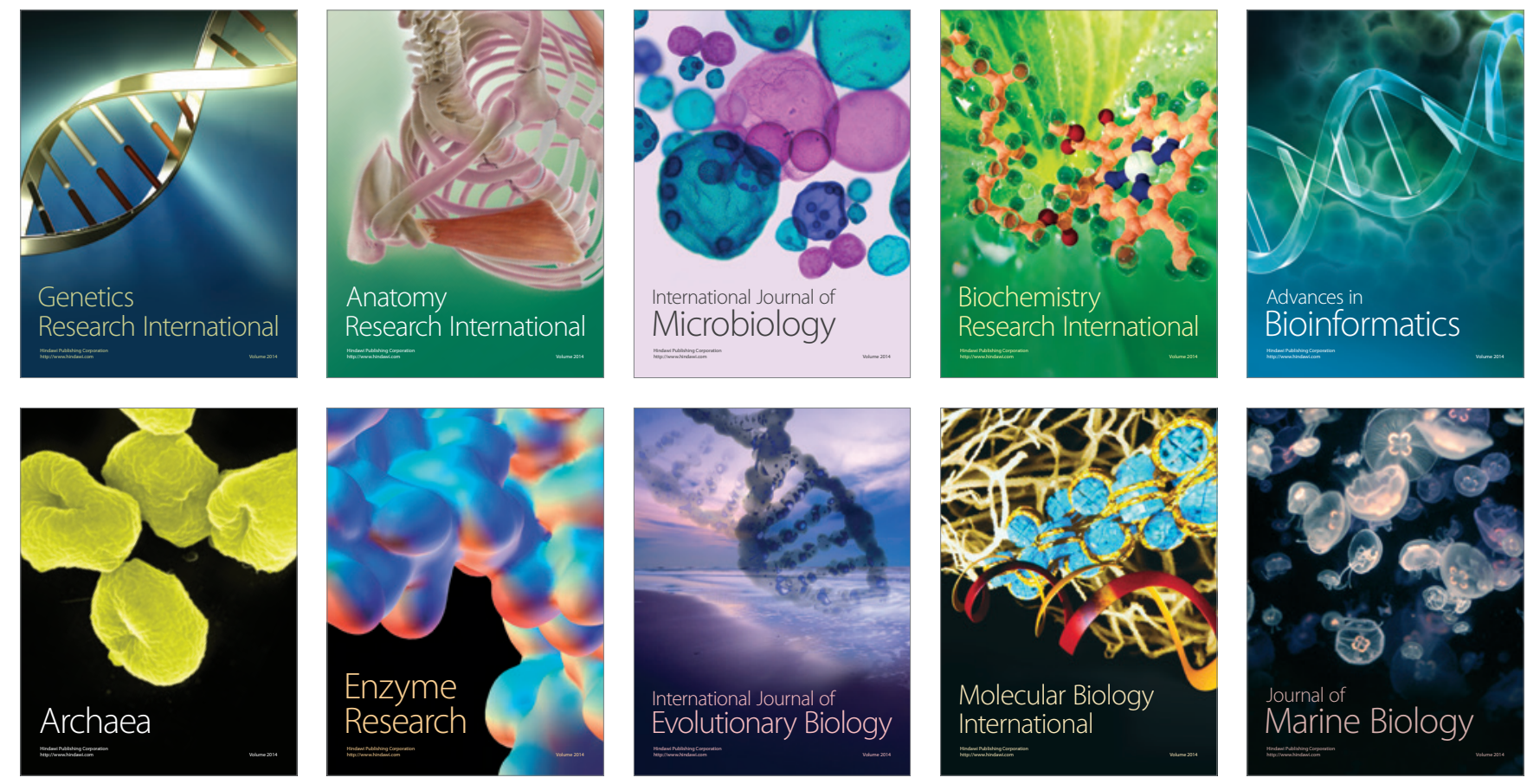